Note: This is a pre-copy-editing, author-produced PDF of an article accepted for publication in Journal of Advanced Nursing following peer review. The definitive publisher-authenticated version [Melby $\mathrm{V}$, Boore JRP and Murray M (1992) Acquired immunodeficiency syndrome: knowledge and attitudes of nurses in Northern Ireland, Journal of Advanced Nursing, 17, 1068-1077] is available online at http://www3.interscience. wiley.com/journal/118486802/toc

\title{
Acquired immunodeficiency syndrome: knowledge and attitudes of nurses in Northern Ireland
}

\author{
V. Melby RGN BSc(Hons) MPhil \\ Lecturer
}

\author{
J. R. P. Boore BSc PhD SRN SCM RNT \\ Professor and Head of Department, Department of Nursing and Health Visiting
}

\author{
M. Murray BSc PhD ABPsS \\ Senior Lecturer, Department of Psychology, University of Ulster, Coleraine, Northern Ireland \\ Published in: Journal of Advanced Nursing, 1992, 17, pp.1068-1077 \\ Copyright: Wiley-Blackwell
}

The number of people suffering from conditions associated with HIV infection is growing steadily. These people require care from nurses who should be well trained to undertake all the various aspects of nursing care. Surveys have indicated that health professionals associate AIDS with minority groups such as homosexuals, drug-abusers and prostitutes. Incidents of sub-optimal nursing care of AIDS patients, or suspected AIDS patients belonging to these minority groups, have been well documented. Surveys have revealed much ignorance and confusion among the general public as well as among health professionals with regard to this controversial syndrome. This study aimed to measure nurses' knowledge and attitudes towards homosexuals, drug-abusers and prostitutes, who through their lifestyle are at increased risk for HIV infection. Questionnaires were distributed to a random sample of 800 nurses in Northern Ireland. The sample was stratified by several demographic variables. A response rate of almost $60 \%$ was achieved. Nurses appeared to have a moderate knowledge of issues related to HIV infection, but there were large gaps in their knowledge of the terminology used in HIV infection. Nurses were not extremely worried about AIDS itself. However, homosexuals, prostitutes and drug-abusers were seen to be at least partly responsible for their own illness. Implications for nursing care and for nurse education are discussed.

\section{INTRODUCTION}

Nursing care of AIDS patients appears to be surrounded by some form of mystique, as if it is different from nursing care of other patients. It is true, of course, that some aspects of the nursing care of AIDS patients are different from the nursing care of other patients. This difference lies not in the actual care itself, but has evolved from the various psychosocial and ethical issues surrounding AIDS.

The Royal College of Nursing AIDS Working Party (1986) stated that it is the responsibility of all nurses to ...offer appropriate and meaningful care to the sick. There is no 'opt-out' clause for caring for patients with AIDS/HIV related diseases. 
They further emphasized that any nurse who refuses to care for AIDS patients lays herself open to disciplinary action.

\section{Nurses' knowledge}

Several studies have attempted to assess nurses' knowledge of HIV-related issues. A recent project by Akinsanya \& Rouse (1991) at Anglia Polytechnic surveyed the knowledge and attitudes of hospital nurses in England to people with HIV/AIDS. This study identified a need for further intensive HIV/AIDS education and training programmes to strengthen the knowledge base for practice. The findings from this study exposed poor attitudes towards people with HIV/AIDS, and recommended urgent action to redress this situation.

Studies by Bond el al. (1990a,b, 1991) examined community nurses' knowledge and attitudes in England and Scotland. Limited knowledge with regard to many aspects of HIV/AIDS was demonstrated, and it was suggested that fear plays a powerful role in influencing personal beliefs about certain patient groups.

Thus, the general picture emerging from these and other studies (Armstrong-Esther \& Hewitt 1989, Mason 1989, Van Servellen el al. 1988) portrays a lack of understanding of many issues associated with HIV infection. Stanford (1988), and many other authors, have pointed out the potential adverse effects of inadequate knowledge on nursing care.

Lack of knowledge about AIDS is a serious problem, in that it is difficult for a nurse to plan and evaluate nursing care if she does not know the relevant facts. Inaccurate knowledge, however, is potentially dangerous, in that totally inappropriate nursing interventions may be carried out.

During the early stages of the AIDS era, extreme restrictions were noted in several countries. A news article in the journal Hospitals (1983) reported the excessive precautions employed by nurses at St Michael's Hospital, New Jersey. A critical nurse specialist at the hospital said that

... we insist that gowns, double gloves, head coverings, shoe coverings, and masks be worn by all those who enter St Michael's AIDS isolation unit.

One consequence of inadequate knowledge of HIV infection is that the nurse may refuse to care for an AIDS patient, and the literature reveals several such incidents (Reed et al. 1984, Searle 1987, Valenti \& Anarella 1986). Surveys have indicated that, given a choice, many nurses would refuse to care for AIDS patients, and that many nurses feel strongly that they should have a right to refuse to care for AIDS patients (Akinsanya \& Rouse 1991, Bond et al. 1990b, Gordin et al. 1987, O'Donnell et al. 1987, Wiley et al. 1988).

\section{Homosexuality}

From the very beginning, AIDS was linked with homosexuality. Consequently, general attitudes about homosexuality and homosexual sexual acts enter the picture (Pomerance \& Shields 1989). Terms used in the early 1980s to describe AIDS reflect this. TermB suchras the 'Wrath of God' (WOG), the 'Gay Plague' and the 'Gay Related Immune Deficiency' (GRID) were used consistently by physicians in the United States (Carr \& Gee 1986, Watney 1987, Wells 1985).

It is with regard to this particular issue that many 'religious' persons or 'moralists' speak their mind. Several authors have noted how some of these 'religious' persons claim that AIDS is divine retribution for 'immoral' behaviour (Haburchak et al. 1989, Korkok 1985, Neuberger 1986). 
Bouton el al. (1989) found that Protestant groups in the United States tended to be more fearful of AIDS than other religious groups. Their study also indicated that frequency of church attendance and religious affiliation were related to fear of homosexuals.

Kinnier (1986) reported that, in the past, societies have reacted in rather similar ways to most lifethreatening epidemics. Brandt (1988) noted that, given the considerable fear that the AIDS epidemic has generated, calls for the implementation of compulsory health measures of groups at high risk for HIV infection are not surprising.

With this growing recognition that AIDS is not a 'Gay disease' and that HIV can also be transmitted hetero-sexually, it is not unexpected that prostitutes have been blamed for the spread of HIV into the general population. Richardson (1987) noted that

To be a prostitute is to belong to a normally despised category of women which (like homosexuality) has been linked with disease and contagion.

The main attitude about prostitutes appears to be related to the belief that prostitutes serve as a reservoir for HIV infection. This is contrary to evidence from seroepidemiological studies from several countries that demonstrate a low level of HIV infection among prostitutes, although it varies from one country to another (CDC 1987a).

Two main risk factors have been identified by a number of seroepidemiological studies. The first risk factor is associated with the sharing of drug paraphernalia by prostitutes who also are intravenous drug-abusers (IVDA), and the second risk factor is associated with the practice of 'high-risk' sexual activities without the use of barrier methods of contraception. So the important question is, do we view a prostitute as 'high risk' as an infector or as an infectee?

IVDAs do not easily integrate into traditional care patterns. They are often violent, primarily against objects or themselves, but occasionally against other patients or staff. A history of prison sentences for drug use or petty theft is quite common. Des Jarlais \& Friedman (1987) noted that

IV drug users are not just considered different, but are often objects of fear, mistrust, hostility, scorn, and, to a limited extent, pity.

\section{Complex matter}

In the light of such information, caring for AIDS patients becomes a complex matter, incorporating not only nurses' beliefs and feelings about AIDS as a disease but also their associated fears of becoming infected by the patient, further complicated by strong societal, cultural, and personal feelings and beliefs about homosexuality, drug-abuse and prostitution. Prior to this study, no research had been identified covering these issues in Northern Ireland.

\section{Research questions}

Four major research themes were identified:

1 What do nurses know about AIDS and HIV infection?

2 What attitudes, beliefs and opinions do nurses hold with regard to AIDS and HIV infection? 
3 What attitudes, beliefs and opinions do nurses hold with regard to people with AIDS or HIV infection, and to those at risk, or perceived to be at risk, for HIV infection?

4 What are the behaviour implications of nurses' attitudes to people with, or at risk for, HIV infection?

The principal intent of this study was to investigate the relationship between fear of AIDS, fear of homosexuals, attitudes towards drug-abusers and prostitutes, and various aspects of nursing. In order to ascertain nurses' attitudes to the above-mentioned groups, it is important and relevant to know the nurses' background information such as gender, religious preferences, nursing speciality and educational status.

Table 1 Knowledge instrument

\begin{tabular}{lrr}
\hline Areas of knowledge & No. items & Correct scores (\%) \\
\hline General knowledge of HIV & 14 & 43.02 \\
Conditions and complications associated with HIV & 14 & 51.88 \\
Body fluids from which HIV has been isolated & 8 & 51.27 \\
HIV terminology & 8 & 21.12 \\
Risk groups & 10 & 61.14 \\
Overall knowledge & 54 & 46.65 \\
\hline
\end{tabular}

\section{METHODOLOGY Instruments}

Before it was decided upon which method(s) of measurement to employ in this study, a methodological review of similar studies was carried out. Having scrutinized the instruments from these studies, it was decided to use the scales for Fear of AIDS and Fear of Homosexuality developed by Bouton et al. (1987). Both scales were short, consisting of 14 and eight items respectively, and were so general in nature that they could be administered to any group in society. The scales were highly reliable, with Cronbach alpha reliabilities of $0-80$ and $0-89$ respectively. Thurstone's method of equal-appearing intervals was used to construct these scales, and they were scored using Likert's method of summated ratings.

Additional Likert-type scales were constructed to assess:

1 attitudes to homosexuals with AIDS (five items),

2 attitudes to drug-abusers and prostitutes (eight items each),

3 nursing behaviour towards AIDS patients (four items),

4 fear of nursing patients with AIDS (eight items).

All statements were based on beliefs identified in the literature.

For the assessment of knowledge it was decided to modify an instrument developed by Morton \& McManus (1986), resulting in a 54-item knowledge instrument covering the issues presented in Table I.

\section{Population and sample}

The research population was defined as all qualified first-and second-level nurses employed within the National Health Service in Northern Ireland. School nurses were excluded to simplify the sampling procedure. 
A mathematical formulae for standard error put forward by Moser \& Kalton (1971) and Jolliffe (1986) was used as a guide for the estimation of sample size. Subsequently, 800 nurses from a total of about 20000 in Northern Ireland were sampled.

The sample was stratified by geographic location, nursing speciality and nursing grade to ensure, as far as possible, that a sample representative of the nursing population in Northern Ireland was obtained. A simple random sampling technique was employed within each stratum.

The questionnaires were distributed to the sample through hospital and community internal mail systems, and the completed questionnaires were returned (in sealed envelopes) individually or in bulk directly to the authors. Confidentiality was maintained by ensuring that no individual nurse could be identified from the returned questionnaire. The study took place in the summer of 1988 .

\section{RESULTS}

\section{Response rate}

An overall response rate of 59-9\% (479 nurses) was achieved. This must be regarded as good, when compared with similar surveys in the literature that generally have a response rate of about $35 \%$ (see, for example, Pomerance \& Shields 1989, Wills 1987). However, a national study of community nurses in England by Bond et al. (1988) achieved a response rate of 73-8\% after two reminders.

The response rates did not differ significantly between different groups of nurses, except that the response rate in one Health and Social Services Board was somewhat higher than in the other three (Table 2).

\section{Characteristics of respondents}

Of the effective sample, $84-3 \%$ were females and $13-4 \%$ were males. Sixty-two per cent of the nurses were under 35 years of age, and nearly $40 \%$ reported more than 15 years of nursing experience.

With a religious breakdown as shown in Table 3, the categories can be divided into two main religious categories; Catholics (48-0\%) and Protestants (40-8\%). According to recent data available on the breakdown of religious affiliation in Northern Ireland, there are $42 \%$ Catholics and 56\% Protestants (PPRU Monitor 1989). With regard to religiosity, 45-9\% reported weekly attendance at their place of worship.

Table 2 Response rates and distribution of sample by geographic location

\begin{tabular}{lrr}
\hline Area Health and & Response rate (\%) & Distribution of sample (\%) \\
Social Services Board & & 24.8 \\
\hline Southern & 79.3 & 20.0 \\
Northern & 64.0 & 16.7 \\
Western & 53.3 & 31.1 \\
Eastern & 49.7 & 6.2 \\
National Board* & 60.0 & \\
\hline
\end{tabular}

*National Board for Nursing, Midwifery and Health Visiting for Northern Ireland: employs nurse teachers. 
Table 3 Religious affiliation

\begin{tabular}{lrr}
\hline & Frequency & Percentage \\
\hline Church of Ireland & 52 & 10.9 \\
Roman Catholic & 230 & 48.0 \\
Methodist & 13 & 2.7 \\
Presbyterian & 113 & 23.6 \\
Baptist & 13 & 2.7 \\
Free Presbyterian & 4 & 0.8 \\
Other - None & 36 & 7.5 \\
\hline
\end{tabular}

\section{Analysis of scales}

Cronbach alpha reliabilities were carried out for each of the attitude scales. The AIDS Phobia and Homophobia scales adapted from Bouton et al. (1987) showed acceptable reliabilities (a =0-76 and $\mathrm{a}=0-91$ respectively). Some of the other scales showed lower Cronbach reliabilities, and interpretation of these scales incorporated additional analysis such as frequencies of opinion statements and factor analysis.

Factor analyses were carried out on all scales, using the principal-factor-with-iteration method with oblique rotation. Three factors were found to underpin the AIDS Phobia scale, but only one factor was associated with the Homophobia scale. The results were similar to those of Bouton et al. (1987), who named the three AIDS Phobia factors Personal, Public and Contact factors as they were associated with these issues.

Table 4 Individual attitude statements. AIDS and Homosexuality

\begin{tabular}{|c|c|c|}
\hline & $\begin{array}{r}\text { Agree/ } \\
\text { strongly agree } \%\end{array}$ & $\begin{array}{r}\text { Disagree/ } \\
\text { strongly disagree \% }\end{array}$ \\
\hline $\begin{array}{l}\text { A centralized file containing the names of all people } \\
\text { known to have been infected with HIV should be created }\end{array}$ & 63.9 & 20.9 \\
\hline $\begin{array}{l}\text { If I found out that my partner was infected with HIV, I } \\
\text { would still have sex with him/her }\end{array}$ & 6.7 & 71.6 \\
\hline $\begin{array}{l}\text { If a friend or partner had AIDS, I would be afraid to kiss } \\
\mathrm{him} / \mathrm{her}\end{array}$ & 47.2 & 29.2 \\
\hline $\begin{array}{l}\text { Nurses are not at high risk for becoming infected with } \\
\text { HIV through their work }\end{array}$ & 21.5 & 66.4 \\
\hline Nurses should have a right not to care for AIDS patients & 43.0 & 43.8 \\
\hline $\begin{array}{l}\text { The cause of AIDS is completely unrelated to } \\
\text { homosexuality }\end{array}$ & 10.9 & 71.0 \\
\hline Homosexuals contribute positively to society & 36.1 & 44.1 \\
\hline Homosexuality should be against the law & 39.2 & 42.0 \\
\hline
\end{tabular}

Regression analysis was employed throughout. This allowed for testing for statistical significance (sig. $t$ ) between different groups of nurses while controlling for all independent variables. A stepwise multiple regression model was utilized to determine which variable, or combination of variables, would allow the most accurate prediction of nurses' intentions to care for AIDS patients. 
The Phobic Indicator Score was defined as the minimum score required for being classified as 'Phobic', and was equivalent to a cut-off point at $60 \%$. Any score above this was considered indicative of a negative attitude.

\section{Nurses' attitudes}

Some individual statements from the AIDS Phobia, Homophobia and Fear of Nursing Patients with AIDS scales are presented in Table 4. These statements are presented as they represent nurses' perceptions of homosexuals and homosexuality, and may consequently have a profound effect on how nurses care for patients who are homosexuals. Some of these opinions were expressed despite the fact that information on how HIV is transmitted has been widely presented in the nursing literature as well as through other media.

Table 5 presents the scores for the Homophobia and Fear of Homosexuals with AIDS scales respectively. From this one can see that nurses in the Southern Health and Social Services Board, female nurses, enrolled nurses and Protestant nurses presented with the more negative attitudes. No significant differences in attitudes were found between nurses working in different specialities.

Three factors were found to underpin the prostitution scale, associated with the issues of morality, sympathy and public control (Table 6). Nurses expressed a strong moralistic attitude towards prostitutes, in which prostitution was viewed as sinful and immoral. About $56 \%$ of the nurses did not think that prostitution should be legalized. In addition, nurses strongly approved of compulsory HIV testing and medical check-ups of prostitutes.

This desire to register and exercise public control over prostitutes was prevalent among all groups of nurses. However, nurses also expressed a positive and sympathetic attitude towards prostitutes. Moreover, $70 \%$ of nurses agreed that prostitutes should be given free condoms to reduce the spread of AIDS.

Although a clear majority of the nurses exhibited a sympathetic attitude towards prostitutes, a significant difference was found between Catholic and Protestant nurses, with Catholic nurses presenting with the more sympathetic attitude.

Factor analysis extracted three factors that seemed to underpin the Drug-abuse scale. The issues associated with the factors were fear, scepticism, and positive, constructive beliefs (Table 7). The frequency scores of the individual statements indicated that nurses strongly approved of compulsory testing of drug-abusers. Nurses approved of supplying drug-users with free sterile needles and syringes, and this represents a positive and constructive attitude towards a controversial issue. 
Table 5 Attitudes to homosexuals

\begin{tabular}{|c|c|c|}
\hline Independent variable & Mean scores & Sig. $t$ \\
\hline \multicolumn{3}{|l|}{ Fear of homosexuals } \\
\hline Eastern Board & & 20.36 \\
\hline vs. All others & 22.10 & $<0.01$ \\
\hline vs. Southern & 23.00 & $<0.01$ \\
\hline Female & & 21.89 \\
\hline vs. Male & 19.66 & $<0.05$ \\
\hline Enrolled nurse & & 23.51 \\
\hline vs. All others & 21.33 & $<0.05$ \\
\hline vs. Staff nurses & 21.59 & $<0.05$ \\
\hline Catholic & & 20.24 \\
\hline vs. Protestant & 22.63 & $<0.0001$ \\
\hline Phobic indicator score: & & 23.80 \\
\hline \multicolumn{3}{|c|}{ Fear of homosexuals with AIDS } \\
\hline Eastern Board & & 13.39 \\
\hline vs. All others & 14.63 & $<0.01$ \\
\hline vs. Southern & 15.02 & $<0.01$ \\
\hline Female & & 14.41 \\
\hline vs. Male & 13.19 & $<0.05$ \\
\hline Enrolled nurse & & 23.51 \\
\hline vs. All others & 21.33 & $<0.05$ \\
\hline vs. Staff nurse & 21.59 & $<0.05$ \\
\hline Catholic & & 13.71 \\
\hline vs. Protestant & 14.83 & $<0.01$ \\
\hline Phobic indicator score: & & 17.00 \\
\hline
\end{tabular}

When examining the behaviour scale, it was found that a negative intention to nurse AIDS patients was expressed by only $14 \%$ of the nurses, while $58 \%$ expressed positive intentions. These positive intentions were further emphasized when considering the individual item frequencies. Only about $8 \%$ of the nurses would consider quitting nursing if they were compelled to care for AIDS patients. Also, 13-5\% of all respondents said they would volunteer to work with AIDS patients if they had the opportunity.

Behaviour analysis, using a stepwise regression model, indicated that the intention to nurse a patient with AIDS was primarily related to the fear of nursing patients with AIDS (B = 0-32; F= 348; Sig. F: $\mathrm{P}<0-0001)$. This positive relationship is only a statistical anomaly, arising from the fact that a higher score on the fear of nursing AIDS patients is associated with a higher score on the intention scale. This higher score on the intention scale indicates a more negative intention. Thus, the more worry the nurse has about nursing an AIDS patient, the less willing she is in her intention to nurse this patient.

This fear of nursing patients with AIDS in turn appeared to be principally associated with a general fear of becoming infected with HIV (B = 0-62; F = 346; Sig. F: $\mathrm{P}<0-0001)$. 


\section{Nurses' knowledge}

A percentage score was computed for each sub-group and for the overall knowledge of HIV/AIDS (Table I). The results indicated a limited knowledge of AIDS among nurses. In particular, there appeared to be a lack of understanding with regard to the terminology of HIV.

Some individual statements are presented in Table 8. These statements are presented as they have a particular relevance to nursing or to Northern Ireland.

About $70 \%$ of the nurses knew that antibodies to HIV do not give any immunity against AIDS. Seventy-five per cent of the nurses incorrectly thought that AIDS is a contagious disease, and as many as $25 \%$ believed that HIV could be transmitted through casual, non-sexual contact. In addition, a total of $78 \%$ of the nurses thought HIV was easily transmitted by needle-stick injury. This is contrary to epidemiological data available at present (CDC 1987b).

Significant differences were found between certain groups of nurses. Nurses in the Southern Health and Social Services Board had less overall knowledge than nurses from other boards $(\mathrm{P}<0-05)$. Enrolled nurses had less knowledge than registered nurses $(\mathrm{P}<0-01)$, hospital nurses knew less than community nurses $(\mathrm{P}<0-05)$, and nurses working on care of the elderly wards had less knowledge than nurses working in high dependency areas (intensive care, operating theatres, casualty) $(\mathrm{P}<0-05)$.

It was noted before that there was a discrepancy between knowledge and attitudes. In this survey it was established that nurses had a limited knowledge of HIV infection. Although it is difficult to ascertain the exact relationship between knowledge and attitudes, a recent study by ArmstrongEsther \& Hewitt (1990) appears to emphasize a strong cognitive influence in that information disseminated to nurses may have effected attitudinal change. Such an association could at least partially explain why ill-informed nurses display negative attitudes to AIDS. This lack of knowledge, in turn, is better understood when considering that less than $25 \%$ of the nurses had attended any form of in-service training or education on issues related to AIDS.

Table 6 Individual attitude statements — prostitution

\begin{tabular}{lrr}
\hline & $\begin{array}{r}\text { Agree/ strongly } \\
\text { agree \% }\end{array}$ & $\begin{array}{r}\text { Disagree/ strongly } \\
\text { disagree \% }\end{array}$ \\
\hline $\begin{array}{l}\text { Moral factor } \\
\text { Prostitution should be legalized }\end{array}$ & 30.7 & 55.9 \\
$\begin{array}{l}\text { Prostitution is immoral } \\
\text { Prostitution is a sin }\end{array}$ & 66.8 & 19.0 \\
$\begin{array}{l}\text { Control factor } \\
\text { There should be compulsory medical tests of prostitutes } \\
\text { Before admission to hospital, prostitutes should be routinely } \\
\text { tested for HIV }\end{array}$ & 57.3 & 23.6 \\
$\begin{array}{l}\text { Sympathy factor } \\
\text { Prostitutes who become infected with HIV deserve no } \\
\text { sympathy, }\end{array}$ & 79.2 & 12.5 \\
$\begin{array}{l}\text { Prostitutes who get the HIV virus through their activity } \\
\text { should have to pay for medical care }\end{array}$ & 77.0 & 68.9 \\
$\begin{array}{l}\text { Prostitutes should be given free condoms to reduce the spread } \\
\text { of HIV }\end{array}$ & 19.2 & 67.5 \\
\hline
\end{tabular}


Table 7 Individual attitude statements — drug abuse

\begin{tabular}{|c|c|c|}
\hline & $\begin{array}{r}\text { Agree/ strongly } \\
\text { agree \% } \\
\end{array}$ & $\begin{array}{r}\text { Disagree/ strongly } \\
\text { disagree \% }\end{array}$ \\
\hline Moral Fear factor & & \\
\hline Drug-addicts constitute a threat to society & 84.5 & 8.2 \\
\hline $\begin{array}{l}\text { Drug-addicts who become infected with HIV have only } \\
\text { themselves to blame }\end{array}$ & 37.2 & 44.3 \\
\hline Drug-addicts should be compulsorily tested for HIV & & \\
\hline $\begin{array}{l}\text { To control the spread of HIV, long prison } \\
\text { sentences should be imposed for illegal drug-use Scepticism }\end{array}$ & 78.5 & 10.3 \\
\hline factor & 37.4 & 41.4 \\
\hline $\begin{array}{l}\text { In general, drug-addicts do not want to get rid of their } \\
\text { addiction }\end{array}$ & 22.5 & 67.1 \\
\hline $\begin{array}{l}\text { It is a waste of resources to try to treat drug-addicts for their } \\
\text { addiction }\end{array}$ & 3.5 & 90.4 \\
\hline I feel sorry for drug-addicts & 74.7 & 22.0 \\
\hline $\begin{array}{l}\text { Constructive factor } \\
\text { To control the spread of HIV, i.v. drug-addicts should get free } \\
\text { syringes and needles }\end{array}$ & 70.1 & 15.9 \\
\hline
\end{tabular}

\section{DISCUSSION}

There were considerable gaps in nurses' knowledge of AIDS and HIV infection. A serious lack of in-service training on AIDS issues was identified in this study. The absence of detailed, factual knowledge is, at least partly, a consequence of this. The knowledge held by the nurses was probably acquired from the media. Considering the inadequate and sometimes incorrect media presentation of issues surrounding AIDS, it becomes easier to understand why nurses, as well as the public, continue to misunderstand and confuse important issues associated with this stigmatized disorder.

Table 8 Knowledge — individual statements

\begin{tabular}{lrr}
\hline & $\begin{array}{r}\text { Percentage } \\
\text { true }\end{array}$ & $\begin{array}{r}\text { Percentage } \\
\text { false }\end{array}$ \\
\hline A high level of antibodies to HIV means that you have an & & 70.4 \\
immunity to AIDS and are therefore non-infectious (F) & 4.6 & 72.0 \\
AIDS is not a contagious disease (T) & 20.7 & \\
To date, c. 50 people have been diagnosed as having AIDS in & 38.8 & 27.8 \\
Northern Ireland (F) & 78.1 & 9.8 \\
HIV is easily transmitted by needle-stick injury (F) & 62.8 & 24.4 \\
HIV cannot be transmitted through casual (non-sexual) contact (T) & & \\
\hline
\end{tabular}

Correct answer: $(\mathrm{F})=$ False $;(\mathrm{T})=$ True .

Nurses were not excessively worried about AIDS in general, but indicated that they would still employ rather restrictive infection control measures if they had to care for AIDS patients. Nurses were moralistic and restrictive and greatly in favour of public health measures such as compulsory testing of homosexuals, prostitutes and drug-abusers.

There was a strong feeling among nurses that homosexuals, prostitutes and drug-abusers were at least partly responsible for their illness. Nurses were quite sympathetic, though, and were in favour of some controversial health promotion measures to limit the spread of HIV infection. 


\section{Attitudes and knowledge}

Nurses' attitudes to AIDS and the minority groups were partly, but not significantly, influenced by the nurses' level of knowledge. Although the overall trend indicated an association between in-service training and more positive attitudes, there were clear areas in which this was not the case. For instance, although Catholic nurses had less knowledge and experience than Protestant nurses. Catholic nurses still expressed more positive attitudes. There are, therefore, other factors that influence nurses' attitudes, such as social and moral values in society.

Three principal trends were identified. First, there were clear geographical differences, with nurses in the Eastern Health and Social Services Board responding markedly differently from nurses in other areas, particularly the Southern Health and Social Services Board.

Secondly, there was a gender difference, with men presenting with more positive attitudes. Historically, research has shown men to be more restrictive and condemning in their attitude towards homosexuals (Bouton et al. 1987, Glassner \& Owen 1976). Men have generally been viewed as having more authority as well as being more authoritarian than women. Negative attitudes towards homosexuality have been linked with authoritarianism, racist attitudes and religious orthodoxy (Larsen et al. 1983). In this study, men were found to have more positive attitudes towards prostitutes, drug-abusers and homosexuals. $*$ *

Thirdly, there was an association between the dependent variables and nursing grade levels, in that the higher the grade of the nurse, the more positive attitudes she had. Whether this is a purely educational association remains to be ascertained.

Knowledge was not identified as an essential predicting factor of nurses' intentions to care for AIDS patients. Neither overall knowledge nor any specific knowledge issue showed significant associations. Data from this research indicated that the fear of nursing AIDS patients was the essential predicting factor.

This is important when considering that most in-service education programmes for staff tend to be almost completely informational in nature. Gordin el al. (1987) suggested three possible reasons for this lack of correlation between knowledge and behaviour. First, nurses may fail to acquire and assimilate the necessary knowledge through simple lack of attention or effort. Secondly, a strong emotional reaction to the topic of AIDS prevents either the acquisition of knowledge or the transformation of knowledge into appropriate professional behaviour. Finally, nurses may have heard and processed the currently available information, but have rejected it after an intellectually critical evaluation.

\section{IMPLICATIONS FOR NURSE EDUCATION}

Measures to eliminate the fear of AIDS and subsequently the fear of nursing AIDS patients, along with educational objectives to foster more positive attitudes towards minority subcultures, appears to be the recipe to ensure high-quality nursing care of patients with AIDS. Nurse education must be presented in a non-judgemental atmosphere. Factual knowledge acquisition on its own is not enough. Any education must include self-assessment of the nurses' attitudes, to allow each nurse critically to analyse her beliefs and value systems. The method of value clarification was suggested by Farrell (1987). This allows the nurse to examine what is meaningful to her, enabling personal and professional growth. 


\section{Strategy}

There should be an overall strategy on AIDS education in Northern Ireland, with all four Area Health Boards implementing the same programme. This would help to reduce geographical differences, and would be more simple than the present system in which each Area Health Board has its own training programme. A more consistent AIDS education programme to nursing staff throughout the province should result from this.

\section{Future research}

This survey has identified a great need for future nursing research on structural and evaluative aspects of in-service training programmes on AIDS. It is important that nurse education programmes have clearly identified components to tackle ethical and moral issues surrounding this complex disease. This is required to enhance nurses' understanding of the physical, psychological, social and pastoral care of the patient suffering from HIV-related conditions.

\section{References}

Akinsanya J.A. \& Rouse P. (1991) Who Will Care? A Survey of the Knowledge and Attitudes of Hospital Nurses to People With HIV/AIDS. Anglia Polytechnic, Chelmsford, Essex.

Armstrong-Esther C. \& Hewitt W.E. (1989) Knowledge and perception of AIDS among Canadian nurses. Journal of Advanced Nursing 14, 923-938.

Armstrong-Esther C. \& Hewitt W.E. (1990) The effect of education on nurses' perception of AIDS. Journal of Advanced Nursing 15, 63 8-651.

Bond S., Rhodes T., Philips P., Setters J., Foy C. \& Bond J. (1988) A National Study of HIV Infection, AIDS and Community Nursing Staff in England. University of Newcastle upon Tyne (Health Care Research Unit), Newcastle upon Tyne.

Bond S., Rhodes T., Philips P., Setters J., Foy C. \& Bond J. (1990a) HIV infection and AIDS in England: the experience, knowledge and intentions of community nursing staff. Journal of Advanced Nursing 15, 249-255.

Bond S., Rhodes T., Philips P. \& Tierney A. (1990b) Knowledge and attitudes. Nursing Times 86(45), 49-51.

Bond S., Rhodes T., Philips P., Setters J., Foy C. \& Bond J. (1991) Experience and preparation of community nursing staff for work associated with HIV infection and AIDS. Social Science and Medicine 32, 71-76.

Bouton R.A., Gallaher P.E., Garlinghouse PA., Leal T., Rosenstein L.D. \& Young R.K. (1987) Scales for measuring fear of AIDS and homophobia. Journal of Personality Assessment 51, 606-614.

Bouton R.A., Gallaher P.E., Garlinghouse P.A., Leal T, Rosenstein L.D. \& Young R.K. (1989) Demographic variables associated with fear of AIDS and homophobia. Journal of Applied Social Psychology 19, 885-901.

Brandt A.M. (1988) AIDS in a historical perspective: four lessons from the history of sexually transmitted diseases. American Journal of Public Health 78, 367-371.

Carr G.S. \& Gee G. (1986) AIDS and AIDS-related conditions: screening for populations at risk. Nurse Practitioner 11, 25-48.

Centers for Disease Control (1987a) Antibody to human immunodeficiency virus in female prostitutes. Morbidity and Mortality Weekly Review 36, 157-161.

Centers for Disease Control (1987b) Update: human immunodeficiency virus infections in healthcare workers exposed to blood of infected patients. Morbidity and Mortality Weekly Review 36, 285-289.

Des Jarlais D.C. \& Friedman S.R. (1987) Target groups for preventing AIDS among intravenous drug users. Journal of Applied Social Psychology 17, 251-268. 
Farrell B. (1987) AIDS patients: value in conflict. Critical Care Nursing Quarterly 10, 74-85.

Glassner B. \& Owen C. (1976) Variations in attitudes towards homosexuality. Cornell Journal of Social Relations 11,161-176.

Gordin P.M., Willoughby A.D., Levine L.A., Gurel L. \& Neill K.M. (1987) Knowledge of AIDS among hospital workers: behavioural correlates and consequences. AIDS 1, 183-188.

Haburchak D.R., Harrison S.M., Miles F.W. \& Hanon R.N. (1989) Resolving patient feelings of guilt. AIDS Patient Care 3, 42-43.

Hospitals (1983) Management rounds: extreme care taken to stop deadly disease's spread. Hospitals 5 7, 45.

Jolliffe F.R. (1986) Survey Design and Analysis. Ellis Horwood, Chichester.

Kinnier R.T. (1986) The need for psychosocial research on AIDS and counselling interventions for AIDS victims. Journal of Counseling and Development 64, 472-474.

Korkok M. (1985) AIDS hysteria: a contagious side effect. Canadian Medical Association Journal 133, I241-I248.

Larsen K.S., Cate R. \& Reed M. (1983) Anti-black attitudes, religious orthodoxy, permissiveness, and sexual information: a study of the attitudes of heterosexuals towards homosexuality. Journal of Sex Research 19, 105-118

Mason C. (1989) HIV: our attitudes and knowledge. Health Care Management 4, 28-32.

Morton A.D. \& McManus LC. (1986) Attitudes and knowledge about the acquired immune deficiency syndrome: lack of a correlation. British Medical Journal 293, 1212.

Moser C.A. \& Kalton G. (1971) Survey Methods in Social Investigation. Heinemann Educational Books, London.

Neuberger J. (1986) AIDS and the moral majority. Nursing Times 82, 22.

O’Donnell L, O'Donnell C, Pleck J.H., Snarey J. \& Rose R.M. (1987) Psychosocial responses of hospital workers to acquired immune deficiency syndrome (AIDS). Journal of Applied Social Psychology 17,269-285.

Pomerance L.M. \& Shields J.J. (1989) Factors associated with hospital workers' reactions to the treatment of persons with AIDS. AIDS Education and Prevention 1, 184-193.

PPRU Monitor (1989) Continuous Household Survey (No 1). Department of Finance and Personnel, Stormont, Belfast.

Reed P., Wise T.N. \& Mann L.S. (1984) Nurses' attitudes regarding acquired immunodeficiency syndrome (AIDS). Nursing Forum XXI, 153-156.

Richardson D. (1987) Women and the AIDS Crisis. Pandora Press, London.

Royal College of Nursing AIDS Working Party (1986) Nursing Guidelines on the Management of Patients in Hospital and the Community Suffering from AIDS. Royal College of Nursing, London.

Searle E.S. (1987) Knowledge, attitudes, and behaviour of health professionals in relation to AIDS. Lancet i, 26-28.

Stanford J.R. (1988) AIDS, education and nurses; a study of nurses' knowledge and attitudes. Paper presented at the Royal College of Nursing Research Society Conference, Jordanstown, Belfast.

Valenti W.M. \& Anarella J.P. (1986) Survey of hospital personnel on the understanding of the acquired immunodeficiency syndrome. American Journal of Infection Control 14, 60-63.

Van Servellen G.M., Lewis C.E. \& Leake B. (1988) Nurses' responses to the AIDS crisis: implications for continuing education programs. Journal of Continuing Education in Nursing 19, 4-8.

Watney S. (1987) The wrong ideas that are plaguing AIDS. The Guardian, 16 October.

Wells R. (1985) Express train to death. Nursing Mirror 160, 16-18.

Wiley K., Heath L. \& Acklin M. (1988) Care of AIDS patients: student attitudes. Nursing Outlook 36, 244-245.

Wills D.J. (1987) AIDS: a survey of nurses' attitudes. New Zealand Nursing Forum 15, 6-7.

Please use the following citation: Melby V, Boore JRP and Murray M (1992) Acquired immunodeficiency syndrome: knowledge and attitudes of nurses in Northern Ireland (Author postprint) in Journal of Advanced Nursing, 17, 1068- 